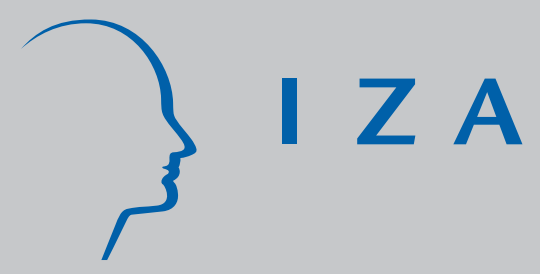

IZA DP No. 2014

Child Care and Parental Leave in the Nordic Countries: A Model to Aspire to?

Nabanita Datta Gupta

Nina Smith

Mette Verner

March 2006 


\title{
Child Care and Parental Leave in the Nordic Countries: A Model to Aspire to?
}

\author{
Nabanita Datta Gupta \\ Danish National Institute of Social Research \\ and IZA Bonn \\ Nina Smith \\ Aarhus School of Business \\ and IZA Bonn \\ Mette Verner \\ Aarhus School of Business
}
Discussion Paper No. 2014
March 2006

\author{
IZA \\ P.O. Box 7240 \\ 53072 Bonn \\ Germany
}

Phone: +49-228-3894-0

Fax: +49-228-3894-180

Email: iza@iza.org

\begin{abstract}
Any opinions expressed here are those of the author(s) and not those of the institute. Research disseminated by IZA may include views on policy, but the institute itself takes no institutional policy positions.

The Institute for the Study of Labor (IZA) in Bonn is a local and virtual international research center and a place of communication between science, politics and business. IZA is an independent nonprofit company supported by Deutsche Post World Net. The center is associated with the University of Bonn and offers a stimulating research environment through its research networks, research support, and visitors and doctoral programs. IZA engages in (i) original and internationally competitive research in all fields of labor economics, (ii) development of policy concepts, and (iii) dissemination of research results and concepts to the interested public.
\end{abstract}

IZA Discussion Papers often represent preliminary work and are circulated to encourage discussion. Citation of such a paper should account for its provisional character. A revised version may be available directly from the author. 


\section{ABSTRACT \\ Child Care and Parental Leave in the Nordic Countries: A Model to Aspire to?*}

The Nordic countries have remarkably high participation rates of mothers and a moderate decrease of fertility rates compared to other western countries. This has been attributed to the fact that the welfare state model and, especially, the family friendly policies chosen in the Nordic countries are unique. The availability of generous parental leave schemes including high compensation rates makes it possible for mothers to take a considerable time out of work in connection with childbirths and to return to their previous jobs afterwards, thanks to the high provision of public daycare. In this paper we evaluate family-friendly policies in the 'Nordic model' with respect to the two modes of child care i.e. either parental care facilitated by maternal and parental leave schemes or non-parental publicly provided care. Our questions for discussion are: Is there a 'Nordic model', and is it worth the cost if effects on child development and welfare are included? Is there a trade-off between family-friendly policies and family welfare, and are there serious negative boomerang effects of familyfriendly policies on women's position in the labor market? Is the 'Nordic model' a model to aspire to?

JEL Classification: J1, J2, D1

Keywords: family friendly policies, labour supply, gender wage gap, fertility, public expenditures

Corresponding author:

Nina Smith

Aarhus School of Business

Department of Economics

Prismet, Silkeborgvej 2

DK 8000 Aarhus C

Denmark

Email: nina@asb.dk

\footnotetext{
* We thank Gösta Esping-Andersen, Marianne Simonsen, Tor Eriksson, and Olli Kangas for commenting on the manuscript, Maria Stanfors for providing useful information on the Swedish parental leave system and Inga Perssons and other workshop participants at Lund University for helpful suggestions. All remaining errors are the responsibility of the authors.
} 


\section{Introduction}

The Nordic countries, i.e. Denmark, Finland, Iceland, Norway and Sweden, have been considered the forerunners in designing family-friendly policies. In a detailed study of familyfriendly policies across OECD countries, Nordic countries led on most of the family-friendly policy indices (OECD, 2001). At the same time, these countries have succeeded in maintaining a high rate of female labor force participation without reducing fertility to the low levels characterizing many other European countries. Thus, the Nordic countries seem to be better prepared to tackle the challenges for future welfare states posed by an ageing population.

Nordic countries have traditionally also been considered leaders with respect to equal opportunity and women's position in society and the labor market. Scandinavian women were among the first to get equal pay by law, though not necessarily in practice. They have also had extended rights to receive social income transfers compared to women in most other countries because of the principle of means testing against individual rather than family income for many income support schemes, and also because taxation schemes in some of these countries have been based predominantly on individual and not family income since the 1970 s. $^{1}$

The high labor force participation rate of women has gone hand in hand with the expansion of the welfare states in the Nordic countries. The large increase in public services directed to child care (besides extensive services related to care for the elderly and the disabled) implied that women were able to leave the home and enter the labor market, often employed in the public sector in care jobs, but now for a salary instead of doing unpaid housework. The expansion of the welfare state has increased the tax pressure in these countries to the highest level in the world, but despite high tax levels, the Nordic countries are among the richest in the world. 
Although the 'Nordic model' has succeeded in maintaining a high rate of female employment, we conjecture that certain 'boomerang' effects of family-friendly policies have arisen with regard to women's position in the labor market. Generous parental leave schemes at high compensation rates and long leave periods allow mothers to take considerable time out of work in connection with childbirth and to return to their previous jobs, due to job rights and a high provision of publicly subsidized day care. The widespread take-up of these schemes exclusively by mothers, however, may be the reason for an emerging deterioration of women's position in the labor market in these countries. E.g. Swedish and Danish women have experienced a complete stagnation of the gender wage gap and considerable child penalties on wages after the introduction of such schemes. The high participation rates of women and the large proportion of children in non-parental child care may also have consequences for the welfare of children and families and the development of children's cognitive skills. Further, the Nordic model is costly i.e. the proportion of GDP which is allocated to relieve women from their duties at home is high and from a public finance perspective, long and generous parental leaves and high-quality public day care constitute a rather expensive solution at a time when public budgets are under pressure due to the ageing of the population.

In this paper we evaluate family-friendly policies in the 'Nordic model' with respect to the two modes of child care i.e. either parental care facilitated by fairly generous maternal and parental leave schemes or non-parental publicly provided care. Our questions for discussion are: Is there a 'Nordic model', and is it worth the cost if effects on child development and welfare are included? Is there a trade-off between family-friendly policies and family welfare, and are there serious negative boomerang effects of family-friendly policies on women's position in the labor market? Is the 'Nordic model' a model to aspire to? In answering these questions we will restrict the discussion to the leave and child care systems i.e. we will not discuss the effects of taxation of 
couples or subsidies to child families which may also have effects on family behavior and welfare, see Jaumotte (2004) for a recent and comprehensive analysis of the labor supply effects of these schemes for women in OECD countries.

In the rest of the paper, we first describe the historical evolution of child care and leave policies in the Nordic countries. Next, we present effects on female labor supply and employment of the take-up rates of family-friendly measures. Then, we examine the consequences for the development of equal opportunity and a little later on other outcomes; such as fertility, family welfare and the cognitive skills of children. Finally, we analyze the financial costs and benefits of public child care and leave schemes and conclude with an overall assessment..

\section{Leave schemes and child care in the Nordic countries}

Compared to other OECD countries, the maternity leave period is long and the coverage of child care is relatively high in the Nordic countries, as indicated in Figures 1 and 2 which show the number of weeks of paid maternal leave and the proportion of children aged 0-2 years in formal child care (public or private) in the late 1990s. The Nordic countries are clearly in the lead with respect to length of paid maternal leave, which in some OECD countries like the U.S. still does not exist. $^{2}$ With respect to child care coverage, the picture is a little more mixed. While Denmark and Sweden had among the highest rates in the late 1990s, also the U.S. had a very high coverage of child care. Finland, Norway and Iceland had a much lower coverage for 0-2 year old children. This pattern in part reflects the fact that as the leave period is long in Finland and Norway, the coverage for the youngest children is lower, contrary to the U.S. where there is no paid leave period and a relatively high proportion of the youngest children are in formal child care. 
As seen from Figures 1 and 2, there are many similarities but also important differences between the five Nordic countries with respect to the design of family-friendly policies. In some of the Nordic countries, especially Finland, the main thrust has been on allowing a long maternal leave period i.e. subsidized child care at home, so that publicly provided child care coverage has been low. At the other end of the spectrum is Denmark, where public child care coverage has been high during the last few decades, while the paid maternal leave period, until recently, has been fairly short compared to the other Nordic countries. Beside leave schemes and publicly provided child care, there are other schemes allowing paid absences to take care of sick children and other care days for children which are not described in this paper.

(Figures 1 and 2 here)

Before describing the systems in the Nordic countries, a few concepts and definitions should be made clear. We define maternal leave as a leave period that is reserved for the mother. If the leave is transferable between the father and mother, the leave period is denoted instead as parental leave. ${ }^{3}$ In most countries there is a short period of leave, typically 2 weeks, for the father immediately following the birth of the child. We denote this father-leave period (which can be used by the father even though the mother is also on leave) as 'daddy days', see Haataja and Nyberg (2005). A leave period which is reserved for the father i.e. which is not transferable to the mother and which does not fall under the category of daddy days is denoted as paternal leave or 'father's quota leave', reflecting the fact that the leave is given to the individual as a quota, and not to the family.

\section{Maternal, paternal and parental leave}


Maternal and parental leave in the Nordic countries has a history of more than 100 years! In Sweden, the right to four weeks of unpaid maternal leave was introduced as early as in 1901, as part of a voluntary state-subsidized sickness insurance scheme. More than 50 years later, in 1955, a 3 months paid maternity leave was introduced in Sweden, as the first country among the Nordic countries. In 1980, Swedish fathers got the right to 2 weeks of daddy days. Sweden was also the first to introduce parental leave. Since 1974, fathers could use part of the leave period, instead of mothers. The leave period was extended to 7 months in 1975, 9 months in 1978, 12 months in 1980, and 15 months in 1989. In 1994, the leave period was reduced again to 12 months when the ruling right-wing government introduced a benefit for homemakers. This was abolished in 1995 and the parental leave was reformed along liberal lines. For example, until 1995, the leave months could be shared between the parents without any restriction. However, in 1995, a father quota and mother quota each of 1 month was introduced, and the leave period was extended to 16 months i.e. 14 months could be shared without restriction, while one month was reserved for either parent i.e. if the parent did not use it, it was lost. The father quota was extended to two months in 2002, and for the first time, the share that mothers could take was reduced correspondingly by one month, see Haataja and Nyberg (2005).

Norway followed Sweden’s example by introducing paid maternal leave already the year after Sweden, in 1956 (see Rønsen (2004)). A 12-week maternity leave was put into place. This scheme was extended to 18 weeks in 1977 and fathers became entitled to take part of the leave period, except for the first 6 weeks after birth. The Norwegian scheme was extended several times during the 1980s and 1990s. In 2005, the leave period was 52 weeks. Since 1993, 4 weeks of the parental leave have been reserved for the father i.e. a father quota of 4 weeks; see Rønsen and Sundström (2002). 
Finland introduced a 9-week paid maternal leave in 1964, see Rønsen (2004). Previously, the option was open through voluntary sickness funds and employer-provided schemes. This period was extended to 12 weeks in 1972 and to 29 weeks in 1974, and then followed by a number of extensions in the 1980s. In 1981, the Finnish maternal leave was as long as 43 weeks (including 5-8 weeks before birth). Fathers became entitled to daddy days in 1978, and by 1980, Finnish fathers were allowed to use 4 weeks out of the mother's leave period, but only with the consent of the mother. Since 1985, Finnish fathers and mothers have been allowed to share the leave period, except for the weeks before birth and the first 14 weeks after birth, which are reserved for the mother. In 1991, Finnish fathers received an individual right to daddy days i.e. without reducing the mother's leave period. In 2005, the Finnish leave period was 54 weeks, the first 20 weeks for the mother, then 32 weeks of parental leave and further, a father quota of 2 weeks. However, fathers have to take at least two weeks of parental leave in order to earn the two weeks of paternal leave/father quota, see Haataja and Nyberg (2005).

In Denmark, a universal paid leave scheme of 14 weeks was introduced in 1967. In 1984, a parental leave scheme was introduced which allowed one of the parents to take 10 weeks of leave after the 14 weeks of maternal leave. Further, Danish fathers got the right to 2 weeks of daddy days in connection with child birth. In 1992-94, a child care leave scheme was introduced, allowing one of the parents to take a leave period of up to 52 weeks per child aged less than 9 years. The generosity of the child care leave scheme was gradually reduced during the years after 1994, and the scheme was abolished in 2002 where the parental leave period (after the maternal leave period of 14 weeks) was instead extended from 10 to 32 weeks. During a short period, 19992002, Denmark also had a father quota of 2 weeks, week 25-26 after birth. Currently, Denmark is the only Nordic country without a formal father quota. 
In Iceland, the leave schemes came a little later. In 1980, mothers became entitled to a 3month leave period. Fathers were allowed to take up 1 of the 3 months of the leave. The leave period was extended further during the 1980s and by 1990 it was 6 months long. In 2000, a rather radical reform was introduced, which allotted a 3 months leave for the mother, a 3 months parental leave period which could be used by either parent, and a 3 months paternal leave for the father. The reform was implemented in three steps: in 2001 the father quota was one month, in 2002 it increased to two months and in 2003, to three months. If the father did not use his 3 months, these months were lost to the family.

Take-up of the leave schemes is high in all Nordic countries. This behavior reflects the fact that coverage is typically almost universal, due to a combination of rules and the fact that virtually all potential mothers participate in the labor force. Mothers in Denmark typically use the full length of their maternal leave and almost all of the parental leave, while Swedish women make use of the flexible Swedish schemes and have often saved a part of the leave for later use, see Pylkkänen and Smith (2004). This means that extensions of the maternal leave period have typically implied a corresponding increase of the average time that mothers have spent on maternal leave.

Compensation rates during maternity and parental leave have varied over time. In general they have become more and more generous. In Sweden, Iceland and Norway, the replacement rate for most of the period is $80 \%$ of former wage income up to a maximum ${ }^{4}$, while in Finland the compensation rate is $66 \%$ for most of the period, see Rønsen and Sundström (2002), although 70\% of the average wage level since $2005 .^{5}$ In Denmark, the compensation rate is $90 \%$ of former earnings up to a flat rate, which is quite low, giving on average a compensation rate of about $66 \%$, see Pylkkänen and Smith (2004). However, the compensation rate is $100 \%$ in the public sector (for 
the first 24 weeks), and since 2004 the majority of private sector employees have full compensation of former earnings during the maternal leave period, but not during parental leave.

The compensation structure of leave schemes has important consequences for the incentives to take up leave, especially the incentives for fathers to take up a short or a long leave, i.e. leave periods in excess of the 'daddy days'. Since fathers, also in the Nordic countries, tend to earn higher income than mothers, the replacement rate of former earnings is a key parameter. In the case of full compensation i.e. a replacement rate of $100 \%$, the incentives are neutral with respect to which parent takes up the scheme. If less than $100 \%$, and especially in case of a flat rate at a fairly low level, there will be economic incentives for the parent with the lowest earnings to take up most or all of the parental leave. Since none of the Nordic countries offer full compensation, there are economic incentives for mothers to take up most of the parental leave. In Denmark, the economic incentives for mothers have been even more pronounced, since the public sector where more than half of the women are employed (and only $20 \%$ of the male workforce is employed) has a $100 \%$ replacement rate. This means that in many families, the mother will get full compensation while the father - typically employed in the private sector - will get a compensation rate of on average only $66 \%$.

Another important aspect of the leave schemes is flexibility of take-up, for instance by allowing part-time leave over a longer period instead of full time leave in a shorter period or by letting parents save part of the leave for later use when the child is older. In all Nordic countries, the schemes have become more and more flexible over time, and a number of different flexibilityenhancing aspects have been introduced. Again, Sweden is probably the country with the most flexible scheme, while the schemes are less flexible in Denmark and Finland.

\section{Publicly provided child care}


The expansion of the Nordic welfare states went hand in hand with large investments in publicly provided child care for preschool children. Publicly provided child care is here defined as child care centers and publicly employed child minders who take care of children in their own home. As indicated in Figure 2, there are also large differences between the Nordic countries in this area. There are two opposing tendencies with respect to coverage. On the one hand, overall coverage tends to increase as a result of a still expanding service level of the Nordic welfare states. On the other hand, coverage for the youngest children has gone down as a response to extended maternal and parental leave schemes.

Denmark is in the lead with respect to providing public child care for especially the youngest children where about half of the children aged 0-2 years are in publicly provided child care, see Table 1. It is mainly publicly provided care for the youngest children aged less than 1 year which has been high in Denmark (and Iceland), reflecting the fact that maternal and parental leave schemes have been shorter in Denmark than in the other Nordic countries. At the other end of the spectrum is Finland, where the leave period has been long (and further, a subsidy for child care at home has existed up until the child is aged 3). The coverage of publicly provided child care is lowest in Finland, compared to the other Nordic countries, for all age groups. The difference is much less pronounced when it comes to coverage of children aged 3-6. However, Finland stands out as being the country where publicly provided child care coverage is low, also for this agegroup, compared to the other Nordic countries. ${ }^{6}$

(Table 1 here) 
School starts relatively late, typically at the age of 6-7 years, in the Nordic countries cf. 4-5 years in Anglo-Saxon countries. Thus, child care arrangements are necessary until the children reach school age, and also for school-aged children, after-school child care services are necessary, primarily because schools have relatively short hours, compared to many other European countries. The price of publicly provided child care is generally fairly low and quality is high in the Nordic countries because child care is heavily subsidized by the state or municipality, see the extensive surveys in OECD (2002b, 2003, 2004, 2005). In Sweden and Denmark, the staff-to-child ratio is typically 1:6 for preschool children, while in most other OECD countries this ratio exceeds 1:10. According to Jaumotte (2004), in 1995 the annual public subsidy to child care per preschool child amounted to about USD 8000 in Denmark, about USD 6000 in Norway and Sweden, about USD 4000 in Finland, and slightly less in Iceland. These figures can be compared to subsidies of about USD 1800 in the US and UK, and USD 3-4000 in Germany and France. It is mainly the subsidy for child care for 0-2 year old children, which is outstanding in the Nordic countries, while the figures are more average for the age group 3-5 where child care is often considered 'education' or schooling (for instance France) and is subject to a $100 \%$ subsidy.

\section{A 'Nordic Model' for the Care for Children?}

The description of leave schemes and publicly financed and provided child care in the Nordic countries clearly shows large differences across these countries. A fair question to pose is whether it is indeed appropriate to talk a bout a 'Nordic model' for child care and family policies?

There are apparent differences between the Nordic countries with respect to strategies i.e. a 'mother employment/public child care strategy' as in Denmark or a 'mother on leave/private child care strategy' as in Finland. It is also true that some other countries outside the Nordic region have high coverage of child care (like France) and high female full time participation rates (for instance 
U.S., Canada, France). Nevertheless, it is fair to say that the Nordic countries have been characterized by an overall ‘family policy strategy' where the state started intervening decades ago in the private sphere to try to alleviate the conflicts between motherhood and work life, while in most other Non-Nordic OECD welfare states, having a baby was considered a private event which was supposed to be handled either by the market or by the family or other private organizations. Thus, from this perspective it seems fair to say that there is a Nordic Model for child care.

\section{Effects on parents’ labor supply and employment rates}

Women in the Nordic countries were among the first in the OECD countries to massively enter the labor market in the 1960s and 1970s, see Jaumotte (2004). Nordic mothers are still in the forefront with respect to employment, although women in many other OECD countries are approaching the level of Nordic women. Figure 3 shows the employment rates of mothers with children aged less than 6 years in 1999. Denmark, Sweden, and Norway have the highest employment rates among mothers of preschool children, while for Finland the employment rates are now lower than in the other Nordic countries.

The historical development of female labor supply has been different for the Nordic countries. Female entrance into the labor market started very early in Finland, where a large proportion of women started to work full time already during the Second World War because so many Finnish men served during the war. In the 1960s female participation started to increase in Denmark and Sweden, although a little later in Norway and Iceland, see Figure $4 .^{7}$ This was the period of expansion of the publicly provided child care and the maternal leave schemes. During the last few decades, participation rates have been reduced, despite the fact that labor force participation rates are to some extent boosted because the majority of mothers on leave are 
registered as members of the labor force. However, at the same time, weekly hours of women in the labor force have been increasing because part time employment is becoming less widespread. Most of the young Nordic women in the labor force are now full timers while two decades ago, up to half of the working mothers were working part time, OECD (2004).

(Figures 3 and 4 here)

Maternal and parental leave schemes have been found to have positive effects on women's participation in the labor market, see for instance Ruhm (1998), Waldfogel (1998), Waldfogel et al. (199), and Jaumotte (2004). Formal rights to maternity leave make it easier for mothers to keep a formal attachment to their previous job and employer, and means that mothers do not have to start 'from scratch' when returning to the labor market after the childbirth and childrearing period. However, where these rights already exist, extensions of the rights and prolonging the maternity leave period from a certain point on may have the opposite effect, see Rønsen and Sundström (2002) and Haataja and Nyberg (2005), because long periods on maternity leave imply career interruptions, and thus, a reduced labor supply.

With respect to child care policy, the results are unambiguous: High coverage and availability and subsidized prices of publicly provided child care increase the net return from mothers' labor supply, and thus positive effects on participation rates are expected. This is confirmed by empirical studies, see for instance Gustafsson and Stafford (1992), Pylkkänen and Smith (2004), Hank and Kreyenfeld (2000), Kangas and Rostgaard (2005) and the survey in Jaumotte (2004). A number of studies show that availability of formal child care is more important than the price of child care, see Freeman and Schettkat (2005). A recent paper by Simonsen (2005) 
exploiting regional variation in day care access and prices in Denmark finds that while having unrestricted access to day care significantly increases female employment, increasing the price of day care also has a significant effect and reduces female labor supply.

The Danish model seems to induce the largest participation rates for mothers of young children due to the high weight put on publicly provided child care. An econometric cross-country study of female labor supply behavior controlling for other factors such as income, wages, and taxation shows that Danish mothers with young children do not have a significantly lower labor supply than other women, contrary to the results found for East and West Germany, UK, and Ireland, see Smith et al. (2003). The same results are not found in econometric studies of other Nordic countries; see for instance recent analyses by Pylkkänen (2002). For Finland and Norway, this may partly be explained by the co-existence of schemes which subsidize parents (mothers) to provide own child care at home. These schemes obviously have negative labor supply effects; see Laine (2002) and Schøne (2005).

Rønsen and Sundström $(1996,2002)$ have studied the impact of family policies on the return to work by comparing the post-birth employment activity of Norwegian, Swedish and Finnish women. Both studies analyze the rates of re-entry into paid work after the first birth for mothers in the 1970s and 1980s. The most important finding is that the right to paid maternity leave with job-protection speeds up the return to employment. Women who have this right are much more likely to resume employment. Gustafsson et al. (1996) and Gustafsson et al. (2002) analyze labor force transitions around childbirth and the extent to which lower labor force participation rates of mothers are explained by different family policies. They compare German, Swedish, British and Dutch women and find that family policy schemes have a large impact on the behavior of mothers with respect to returning to work after child birth. 
A crucial question is how large a proportion of the shared leave is taken up by the father i.e. the father's share of the leave period and the take-up rate of father quota leave periods. Here the picture is very different from mothers' take-up. The proportion of fathers who take up daddy days, parental leave and father quota leave is far from $100 \%$. This means that the share of the total leave which is taken up by the father is still relatively low in all Nordic countries, with some interesting variations between the countries. Table 2 shows the share of the total leave that is taken by the fathers in the 5 Nordic countries.

The general picture from Table 2 is that the fathers' take-up of the leave period is still far from 50\%. We do not have consistent time series for a long period except for Denmark and Sweden. For these two countries the story is quite different. In Sweden, fathers' take-up rate has clearly increased, while the opposite seems to be the case in Denmark.

The overall experience from the Nordic countries is, that the introduction of parental leave schemes i.e. the introduction of schemes which can be transferred between the parents does not change behavior much. Mothers tend to take by far the largest proportion of the prolonged period. The take-up by fathers seems to be very sensitive to the rules concerning father quotas and flexibility of schemes. The introduction of father quotas in especially Sweden, Norway and Iceland has changed fathers' share considerably, and these 3 countries are now clearly in the lead with respect to fathers' take-up of leave periods. The introduction of short periods of father quota periods in Denmark and Finland has also had effects on fathers' take-up, but the period is still very short in these two countries, even non-existing in Denmark.

(Table 2 here) 
There are, to our knowledge, no evaluation studies of the Icelandic model, where during the recent years, changes in the leave schemes have seemingly had a very large effect on parents' sharing of leave periods and fathers' involvement. However, for Sweden, where fathers also play an increasing care role, Sundström and Dufvander (2002) have analyzed sharing of parental leave. Among other things, they find that fathers tend to take up a larger share of the parental leave in families with more educated mothers. The results in Pylkkänen and Smith (2004) show that economic incentives and leave periods of fathers affect the behavior of mothers, but the effects are found to be much larger in Sweden compared to Denmark. Pylkkänen and Smith explain this finding by the fact that family-friendly policies in Sweden have focused much more on flexible leave schemes and on shared responsibilities of parents than in Denmark, where the schemes until recently have been very inflexible and where there has been much less political discussion on sharing responsibilities between parents, see Borchorst (2003).

\section{Consequences for gender equality}

The high participation rate of women in the Nordic countries has implied that women in these countries have become much more economically independent of their husband's income than in countries with lower female participation rates. But the growth of public sector employment, the increasing tax pressure in the Nordic countries and the large coverage of family-friendly policies which have mainly been taken up by women, as we document below, have also had boomerang effects on women's position in the labor market.

The gender wage gap and the family gap

The Nordic countries have traditionally had some of the world's lowest gender wage gaps; see Figure 5, which shows the gender wage gap in a number of OECD countries in 1999-2000. One 
explanation for the low gender gap is that solidaric wage policy was an explicit union goal in the Nordic countries for decades, and the resulting compressed wage structure is a major reason for the low gender wage gaps. However, when we look at the female percentile ranking in the common or male wage structure, the Nordic countries are not found to be doing as well, see Rosholm and Smith (1996) and Blau and Kahn (1992).

(Figures 5 and 6 here)

Figure 6 shows the development of the female-to-male wage ratio in the Nordic countries over a 44-year period. During the 1960s and 1970s, the ratio increased substantially though at different rates across the countries. However, the increase in the relative wage ratio has tended to stagnate in most Nordic countries since the beginning of the 1980s. As an example, the ratio of female to male earnings in Denmark has virtually not changed since 1976, the year when the first equal pay act was put into force. The same holds for Sweden, while in Norway and Finland the ratio continued to increase after the mid 1970s, see Asplund et al. (1997). For Iceland, statistical information on the gender wage gap does not exist very far back in time. For the recent years, Figure 6 shows that Iceland has the largest gender wage gap among the Nordic countries.

The development during the last few decades in the Nordic countries is contrary to that in the U.S. where the gender wage gap has been strongly reduced during the 1980s and early 1990s, despite rising U.S. inequality over this period cf. U.S. women were "swimming upstream" in this period see Blau and Kahn (1997). In contrast, Scandinavian women seem to be floating downstream or even stalling in their quest for wage equality, despite a much more compressed 
wage structure and the expansion of a number of family-friendly policy initiatives during this period, Datta Gupta et al. (2006).

Again a number of explanations behind this development in the Nordic countries may be put forth, see Rosholm and Smith (1996) and Edin and Richardson (2002). Macro economic conditions changed after the first oil crisis in 1973. Unemployment increased in many European countries and sectoral changes and changes in industry wage differentials had negative effects on women's pay. The automatic wage indexation (which typically gave a higher compensation to low wage groups i.e. favoring female dominated groups) was suspended in some countries in the late 1970s and early 1980s. At the same time, the wage formation process became more decentralized and solidaric wage policy came to an end. In a recent micro-study of 22 countries, Blau and Kahn (2003) demonstrate that highly centralized wage bargaining settings increase female wages relative to male wages by setting wage floors at the bottom of the distribution where females tend to be located, and therefore decentralization should adversely affect the gender wage gap. Thus, other forces than family policy have clearly affected the gender wage gap.

However, two recent studies which analyze changes in the gender wage gap over time in Sweden and Denmark, both document the stagnation of overall relative female wages and uncover interesting characteristics when looking at different parts of the wage distribution, see Albrecht et al. (2003) and Datta Gupta et al. (2006).. When comparing the different deciles of the wage distribution, both studies find that it is only in the upper part of the wage distribution that the gap is increasing. In the lower part of the wage distribution i.e. $1^{\text {st }}$ decile, the Danish gender wage gap has continued to decline by $-2.4 \%$ during the period 1983 to 1995 , while in the U.S. the same figure was $0.3 \%$ i.e. a slightly increased gender wage gap at the bottom of the distribution, see Table 3 . However, high skilled Scandinavian women i.e. $9^{\text {th }}$ decile, seem to float downstream. Here the 
gender wage gap increased by $14.8 \%$, while similarly qualified U.S. women at the top of the distribution reduced their gender wage gap by $10.3 \%$. When controlling for changes in observed characteristics such as education and experience, this development is even more pronounced because Danish women during the same period have, to a large extent, caught up with their male colleagues in terms of these qualifications.

(Table 3 here)

What can explain this development in the gender pay gap in the Nordic countries? It is important to stress that the wage structure observed in Denmark and Sweden is not only a Scandinavian phenomenon but can be found in many other European countries, see Arulampalam et al. (2004), who point to glass ceilings (i.e. large gender wage gaps at the top of the wage distribution) in many European countries. Also for the U.S. there is evidence that the tendency of equalization of male and female wages stagnated during the 1990s mainly because of a changing demand and supply structure which was less favorable to women in the 1990s compared to the 1980s, see Blau and Kahn (2004). A number of hypotheses might be put forth, some of which are relevant for many European countries and the U.S., and some of which may mainly be relevant for the Nordic countries.

First, a number of studies have analyzed the wage effects of career interruptions due to child birth. The results from these studies are rather mixed. Some studies have found that career interruptions and loss of human capital accumulation have a negative effect on women's wages, while others find this effect to be only temporary and women who give birth seem to catch up with non-mothers some years after returning to their job, see for instance Waldfogel (1998) for the U.S., 
Albrecht et al. (1999) for Sweden, Datta Gupta and Smith (2002) for Denmark, and Hardoy and Schøne (2004) for Norway. In these studies, the major focus is on the family gap i.e. a comparison between mothers and non-mothers, which may be different from a comparison between mothers and fathers or men in general. Datta Gupta and Smith (2002) show that despite there not being a permanent effect of career interruptions on the family pay gap, there is a tendency that all women seem to have flatter wage profiles during the child bearing ages when controlling for observable factors. These findings may reflect that in a regime with an almost $100 \%$ coverage of leave schemes and where the gender distribution of take-up rates is very skewed i.e. women take up close to all of the total leave period, there may be negative effects of parental leave schemes on all women's wages, not only on mothers' wages. These effects possibly reflect employer statistical discrimination which may not be nearly as important in regimes where only a minority of the employed mothers have the right to maternal and parental leave and take up these leaves, or in regimes where the gender distribution on leave periods is more balanced so that mothers and fathers share the leave more equally, as in Iceland and to some extent Sweden.

The small wage penalties on the individual mother in regimes with a universal coverage of maternal leave may further be combined with negative signal effects for the few fathers who choose to stay at home for a period. In a regime where there is no father quota and few men take up parental leave, there may be a much larger negative wage effect or penalty for men on leave than in a regime where a large proportion of men take up parental leave or where there is a father quota. The negative effect may be a sort of 'signal effect'. When very few men are on parental leave, it may be a much more negative signal for a man to take up parental leave compared to a woman, because all women tend to take up their leave period while only few men do so, see Albrecht et al. (1999) who find this result for Sweden based on data from the period before the 
Swedish father quota was introduced. This may reinforce the selection process. In order to disrupt this 'equilibrium' it is necessary therefore to introduce father quotas, which reduce the negative signaling effect.

The results showing no negative individual long-term effect on women's wages have been challenged in a recent study for Denmark. Nielsen et al. (2004) show that in a wage model that controls for the endogenous choice between public and private employment, there is actually a large and permanent negative effect on the family gap for privately employed women taking a career break of one year due to child birth. For women employed in the public sector, the study finds no significant effect of a career break. Their study is based on a panel sample of Danish women, and finds that women who would face the highest penalities therefore, tend to select into the public sector when they become pregnant or shortly after child birth. ${ }^{8}$

This self-selection on the part of women between public and private sector employment may be seen as a rational family reaction to the employment conditions in the two sectors. During the past few decades, public sector unions (many of which are dominated by women) in the Nordic countries have given strong priority to improving family-friendly schemes, see Rosholm and Smith (1996). For instance in Denmark, the compensation rate during the first 6 months of maternal and paternal leave has been $100 \%$ of former wage in the public sector at the expense of general pay increases. In general, the working conditions in the public sector have been much more familyfriendly than in the private sector with respect to rights to part time employment, care days etc.

A 'welfare state-based glass ceiling'?

The combination of very generous family-friendly schemes mainly in the public sector and high public sector employment in all Nordic countries (partly because the Scandinavian welfare state has taken over a lot of care functions from the private households and these services are 
instead produced by the public sector) may have led to the re-emergence of a new type of male breadwinner society where mothers (women) select into relatively low paid jobs ${ }^{9}$ in the public sector where it is easy to combine a career with family responsibilities while men tend to locate in the private sector, have a low rate of take-up of family-friendly schemes, earn the larger part of household income and support the family. More than half of the female workforce in the Nordic countries is employed in the public sector, while this is only the case for $20-25 \%$ of the male workforce. Labor markets in Nordic countries are among the most gender-segmented labor markets in the world, see OECD (2002a).

How can this system with large pay differences exist over a long period and how can the public sector attract for instance non-mothers, or men and women who also intend to pursue a career? It is, after all, not only mothers who are employed in the public sector. One important factor is that the public sector to a large extent has a monopoly power as the only potential employer for a large fraction of the labor force in the Nordic countries. For a number of educational groups such as nurses, school teachers, care workers, there is only one employer, namely the public sector, which therefore has monopsonistic power when setting wages ${ }^{10}$. Combined with unions' preferences for working conditions improvements at the expense of wage increases, general macroeconomic conditions, tight public budgets etc. this may explain the changing wage structure during the latest decades, see Rosholm and Smith (1996), Nielsen et al. (2004), and Datta Gupta et al. (2006). In the latter it is found that when controlling for observables, the public sector wages in Denmark were 4\% lower than private sector wages in 1983 while this figure had increased to $14 \%$ in 1995 . For the U.S. the same figures for the same years were $4.6 \%$ and $1.8 \%$, respectively. 
Another potential boomerang effect of the Nordic family-friendly schemes may originate from publicly provided child care. There is no doubt that high quality and publicly subsidized child care has a direct positive effect on women's position in the labor market. But here also there may be some negative effects. Publicly provided child care is typically rather inflexible. Though the Nordic day care centers provide full time care, contrary to some other European countries, opening hours are relatively short and moreover opening hours have been often been cut as a response to generally shorter working hours. This means that families with irregular or long working hours may face child care problems because of a lack of flexibility of child care hours. In a study based on Danish time use data, Bonke et al. (2005) find that it is mainly women who tend to pick up children at day care centers, and they further find that doing these time-inflexible types of housework has a negative effect on wages, especially at the higher end of the wage distribution.

A related issue concerns the amount of housework and do-it-yourself work which is done within the household. One hypothesis could be that because of the high tax pressure in the Nordic countries (which to some extent reflects the financing of the family-friendly schemes, public responsibility for care for the elderly and sick persons etc.), households in Nordic countries spend more time on doing these types of non-market activities, see Freeman and Schettkat (2005) who compare EU and the U.S and document the resulting effects on female labor supply. Thus, households in the Nordic countries may devote more time on and energy on non-market activities and less effort and time on market work and careers. This effect may further be reinforced because of the progressive income tax system and fairly compressed wage structures in the Nordic countries because the high effective minimum wages in the labor market implies that housework services are expensive, and thus, even high income families often cannot afford to outsource housework activities. If women are mainly responsible for the home and undertake more non- 
market activities than men, which is still the case in all Nordic countries, this may explain part of the family pay gap.

However, empirical analyses based on time use studies have not been able to document any clear relationship between the allocation of time in the household and the observed wage rate, even when conditioning on different parts of the wage distribution using quantile regression methods, see Bonke et al. (2005). Only when controlling for the flexibility of housework, is there a clear negative effect from doing time-inflexible tasks, as mentioned above. The negative effect is large for men as well as women, but since women tend to do more inflexible tasks, this may explain some part (though small) of the family pay gap, especially for high skilled groups.

Is this effect a special Nordic effect i.e. are the Nordic countries different from at least other European countries with respect to these potential housework and do-it-yourself work effects? Arulampalam et al. (2004) rejects the explanation that the wage dispersion on the market prices of housework services can explain the glass ceiling in Sweden put forth by Albrecht et al. (2003). One reason being that glass ceilings are observed in many European countries, and another reason being that a simple correlation between wage dispersion and the size of the glass ceiling does not give any significant results. However, there may be more than one reason explaining the observed glass ceilings in many European countries. The study by Arulampalam et al. (2004) actually indicates that the structure of the glass ceilings differ between European countries and between public and private sectors. Second, the insignificant calculated correlation found in this study is based on only relatively few observations. Third, it is not only the compressed wage structure but also the combination of a high tax wedge, progressive income taxes, and compressed wages, which makes household services very expensive to buy in the market. But on the other 
hand, it is fair to state that until now, most of these negative boomerang effects of the Nordic model have not been clearly identified and documented.

Summing up, the most important and documented effects from the Nordic family-friendly schemes on equal opportunity and the position of women are all positive with respect to making women more economically independent of their husbands, and second the negative boomerang effects from parental leave schemes arise due to mothers taking on average much longer periods of leave than fathers. Third, the selection effects into the public sector leads to the re-emergence of a sort of a male breadwinner system in Nordic countries with resulting negative effects on the aggregate pay gap between men and women. Particularly, the gender pay gap appears to have widened most at the top of the wage distribution as a result of these policies, which we term a 'welfare state-based glass ceiling'.

\section{Effects on fertility}

Family-friendly policies may also have a number of other effects. To the extent that family decisions concerning fertility are influenced by economic conditions, it is obvious that these policies may impact fertility. According to traditional economic theory, see for instance Becker (1964), children may be considered a normal good, and the economic factors determining the demand for children in a family are the result of income and substitution effects. In regimes without family-friendly policies, a negative trade-off between women's labor supply and fertility should be expected because the costs of having children increase with the earnings potential of the mothers. However, family-friendly policies loosen this trade-off, see Del Boca et al. (2003), and Apps and Rees (2004). Maternal and parental leave schemes reduce the immediate income loss from having a child, and to the extent that these schemes facilitate a more permanent attachment to the labor market there may also be long term cost effects. Further subsidized child care, care days 
etc. reduce the costs of children, see Ahn and Mira (2002), who also find that a large income effect due to women earning higher wages may explain why the relationship between fertility and female labor supply has turned more positive lately. Inequality and risk aversion may also be important determinants of fertility, see Apps and Rees (2004), and thus countries with low inequality and high social safety nets, like the Nordic countries, may experience higher fertility rates.

Simple correlations between women's employment rate and fertility in a number of countries indicate that family-friendly policies seem to have had an effect on this relationship see Table 4. The Nordic countries have had a high female employment rate (age group 25-54 years) during the last few decades and have succeeded in avoiding large drops in fertility. The most interesting country is clearly Iceland which combines the highest employment rates of all countries (86\%) with the second highest fertility rate (1.99). For the rest of the Nordic countries, the employment rate is about $80 \%$ and fertility rate is $1.7-1.8$, which is at the high end of the distribution. Most other European countries hold a rather miserable position from an economic point of view, with low fertility rates, about 1.3-1.4, and low female employment rates (55\%70\%)! The only exceptions are the Netherlands and the UK. In the Netherlands, the explanation is mainly the widespread use of part-time employment for fathers and mothers. It is interesting to note that the U.S., which is far behind Europe with respect to family-friendly policies, lies between the Nordic countries and the rest of Europe with respect to fertility. In the last row of the table, simple correlations between fertility and employment are reported. It is remarkable, that the correlation in 1970 was negative whereas the correlation in 2003 is positive and relatively high. This could indicate that family-friendly policies introduced in the meantime have facilitated the combination of work and family. 
(Table 4 here)

Looking at the research within this area, the empirical evidence for the Nordic countries is rather sparse. Most of the research relates to Sweden. Walker (1995) found that the 'speed premium' which was introduced for Swedish mothers in the 1980s had an effect on the timing of fertility i.e. a shorter duration between child births. However, Björklund (forthcoming) concludes in his study of the relationship between Swedish family policy and fertility that in a long run perspective, there seem to be very small effects of family policy on Swedish women's fertility. The effects may as well be due to other factors, for example macro factors such as cyclical fluctuations, which seem to have had a much larger effect on the fertility of Swedish women during the last few decades. The same ambiguous results are found for Finland and Norway in Rønsen (2004) who finds that extensions of maternity leave duration have a positive effect on fertility, especially in Finland, but contrary to expectations, the coverage of child care seems to have a negative effect on fertility in Finland and Norway. However, Rønsen argues that coverage of child care may in itself be endogenous and highly correlated to women's labor supply and queuing problems in local areas and this may explain the estimated negative relationship.

Thus, the overall research evidence is not clear and does not directly support the hypothesis that family policy in the Nordic countries is the main explanation behind the fact that these countries avoided the large drop in fertility when women entered the labor market. Since we still observe that the Nordic countries have done quite well with respect to breaking the negative relationship, we may return to more general explanations. It may not be family-friendly policies that are important for the continuously high fertility and high female labor participation. It may be the mere existence of social safety nets combined with risk aversion arguments that have had 
positive effects on fertility. But since the fertility level is also high in much more liberal welfare states such as the U.S., there are still a number of unresolved questions within this area.

\section{Effects on family welfare and children's cognitive development}

How do the family-friendly Nordic policies affect family welfare - are families in general satisfied and is publicly provided day care beneficial for children? These are of course very difficult questions to answer, but nonetheless important to consider when making an overall evaluation of family-friendly policies.

To our knowledge, there is no systematic research relating family welfare to the existence of family-friendly policies, one exception being Jaumotte (2004). Different hypotheses might be put forth. Family-friendly policies might increase welfare because they ease everyday life for families with young children, they facilitate women's career plans, contribute to women becoming economically more independent of their husbands and reduce child poverty. Further, parental leave schemes and paternal leave schemes give fathers greater opportunities to be active caregivers and to adopt new roles within the family. On the other hand, this may of course also reduce welfare for some groups i.e. groups within society who do not value women's emancipation for example. Surveys published regularly by Eurostat on life satisfaction have always placed the Nordic countries Sweden, Finland and especially Denmark at the high end of the satisfaction scale, while Southern European countries like Greece, Spain, Portugal, France and Italy have the least satisfied populations. Blanchflower and Oswald (1997) have suggested that personal and marital freedom is an important determinant of life satisfaction among the younger generations, and in this respect family-friendly policies, along with other policies which support individual economic independence may in part explain the high level of life satisfaction in the Nordic EU countries. 
Another question which has been more direct researched concerns the relationship between health and cognitive development of children and family policies i.e. the effects on children from maternity and parental leave schemes and from receiving child care outside the home. A number of research findings point to the importance of the earliest years of children's life for later outcomes, see a recent survey in Waldfogel (2004). There is no doubt that maternal leave periods of a certain length is highly beneficial for children's health and general outcomes. The first period after birth is crucial for creating lifelong bonds between the parents and the child and for breastfeeding.

A number of studies have found that mother's work outside the home is harmful for the cognitive development of their children; see for instance Ruhm (2004) for U.S. evidence and Ermisch and Francesconi (2001) for the UK. However, these studies typically do not control for the quality of substitute child care which is found to be a key factor for the well being, health and cognitive development of children. According to a survey of recent results in Waldfogel (2002, 2004), also confirmed by a recent study by Gregg et al. (2005) for the UK, the main lessons from the empirical research are that parents' care is important but that the quality of child care is even more important. Providing and improving the quality of non-parental care may be an effective way of improving child outcomes. These results give strong support for the Nordic model of public provision of formal child care with its educated and regulated care-givers for children in all agegroups, even in the $0-3$ age group.

Another aspect is social mobility. One important potential long term consequence of publicly provided universal high quality child care is that it facilitates upward social mobility for children coming from low income families, see Esping-Andersen (2004) and the survey in Waldfogel (2004). According to Esping-Andersen (2004), this is exactly what has happened in the Nordic countries. Publicly provided child care in the Nordic countries (mainly the Scandinavian 
countries of Denmark, Sweden and Norway and to a lesser extent Finland and Iceland) has been a universal public service which has been affordable for and available to all families, or at least, selection into high quality care, has not been based on family income but rather through a queuing system which often favors children from deprived families over those from high income families. Esping-Andersen (2004) estimates a cross country intergenerational mobility model for different birth cohorts and finds that social mobility of the younger cohorts has increased in the Scandinavian countries, contrary to the patterns found for the U.S., UK, and Germany.

To our knowledge, there are no studies analyzing the effects of paternal leave and child outcome (nor the effects on families' life satisfaction). An interesting question for future research is whether the new father quota schemes in some of the Nordic countries, especially the very rapid developments taking place in Iceland with respect to fathers' take-up of paternal leave have had any effects on child outcomes.

\section{The financial costs of the public child care and leave schemes}

Nordic family-friendly policies have one clear drawback: it is an expensive system and from a partial equilibrium view these policies are a burden on the public budgets. Table 5 shows the percentage of GDP spent on publicly provided child care and leave schemes in 2002. Child care costs (which also cover care of older children) are much larger in the Nordic countries mainly because of the high coverage and large cost of caring for the very young children, aged less than 3 years. Denmark spent $2.7 \%$ of GDP on public child care, Sweden 1.9\%, Norway and Finland about $1.6 \%$ while Iceland spent $1.1 \%$. The public cost of leave schemes is highest in Sweden ( $0.8 \%$ of GDP) and about $0.5 \%$ of GDP in Denmark and Norway. Compared to the rest of the OECD countries included in Table 5, these figures are very high. In the US and UK, only $0.5 \%$ of GDP is 
spent on public child care and about 0.1 on leave schemes. Thus, Denmark and Sweden spend roughly four to five times as much (measured as a percentage of GDP) as the US and UK.

Rosen (1996) argued that the publicly subsidized family policy system in Sweden where taxes are high in order to finance subsidies for home-provided goods (such as child-care) creates substantial deadweight losses by encouraging women to enter the labor force and produce household services instead of material goods. However, Aslaksen et al. (2000) criticize this analysis by pointing out that there could be welfare gains induced by the positive external effects of high-quality child care and its implied distributional impacts.

There are of course a number of other indirect gains for public sector budgets from familyfriendly policies that are worth mentioning. The potential gains related to increased labor force participation of mothers can lead to a reduction of the obsolescence of mothers' human capital and loss of earnings capacity during child bearing and child rearing periods. Also, the resulting increased fertility has a positive effect on the country's future tax base. Further, the costs of the family-friendly policies and especially the public costs of child care may also be considered compensation to dual earner families because taxes are only paid on market income, while non market work is untaxed. Alternatively, child care costs might be tax deductible. In the Nordic countries where the tax pressure is approaching $50 \%$, these tax incentives may be very important and without child care subsidies and leave schemes, there would be large incentives to undertake non market work, see the survey on public finance arguments for child care and leave policies in Cleveland and Krashinsky (2004), who argue that the total financial net effects on public budgets of these policies are positive when including long term effects resulting from mothers' participation and tax payments, Cleveland and Krashinsky (2004, p. 47). 


\section{Conclusion - a model to aspire to?}

Most European welfare states face serious problems with respect to financing their welfare systems in the upcoming decades because of ageing populations and increased international competition due to globalization. This implies an increased pressure on the relatively high tax levels in many EU countries, especially the Nordic countries which have some of the highest tax levels in the world. The 'Nordic model' with respect to child care is a relatively expensive model is it a model to aspire to?

The answer to this question depends of course on political preferences concerning equal opportunity, family values, and preferences concerning inequality. However, based on an economic perspective and the fact that, formally, equal opportunity is an accepted general goal for all governments the answer must be a 'yes', but with some reservations. The discussion in this paper has indicated that the Nordic countries have arrived at solutions to balancing family responsibilities with market work in a way which seems to be robust to future economic challenges and which have more desirable properties with respect to female labor supply, fertility, children's development and gender equality issues.

However, there are drawbacks to some of the features of the Nordic model. First, the Nordic model is expensive. Denmark and Sweden have the highest tax pressure in the world: 51\% of GDP in Sweden and 49\% in Denmark in 2001. Finland and Norway follow by 46\% and 43\%. Iceland has the lowest tax pressure among the Nordic countries with 'only' 37\%.

A second, and maybe a more surprising, reservation concerning the Nordic model is that the Nordic women no longer seem to hold a clear lead with respect to their position in the labor market, compared to women in other countries who have not benefited from such extensive family-friendly policy schemes. The reason may be that some of the family-friendly schemes have 
serious boomerang effects on women's position in the labor market, especially for the more educated women. To some extent, the Nordic welfare state model may even have created a type of 'system-based glass ceiling': Not the traditional glass ceiling within the individual firms, but a glass ceiling which all women become subject to because of the functioning and design of familyfriendly schemes in the Nordic welfare states. We explain this glass ceiling largely by the fact that women are still mainly responsible for the tasks done at home, and that their take-up rates of maternal and parental leave far exceed that of men's, and by the fact that women tend to crowd into the large public sector which offer the more family-friendly jobs - but at lower wages.

The research results discussed above show that it becomes problematic for women's general position in the labor market when family policy is mainly directed towards giving mothers the right to be on long paid maternal leave or in general become the principal care-giver for the family since mothers become a less valuable workforce for employers in a labor market where still more jobs are subject to high adjustment costs. Statistical discrimination effects may further extend these effects to all women, not only mothers. The negative effects seem to harm especially women at the higher end of the qualification distribution, while women at the lower end seem to have actually benefited from the development during the latest decades. When facing the future challenges posed by an ageing population and increased global competition, it is important to avoid a situation where a large proportion of the work force loses important skills during long periods out of the labor market.

Looking at the specific schemes, clearly differences exist between the Nordic countries. Iceland started somewhat later than the other Nordic countries in introducing a number of welfare schemes. Thus, there is not much research available yet on intergenerational mobility or other effects of the relatively new policies introduced in Iceland. However, Icelandic women have now 
taken the absolute lead with respect to labor force participation, and Icelandic men have had an impressive increase in their take-up of parental leave days. Icelandic women still face considerably lower wages than their male colleagues, but an interesting question for future research will be to study the long term effects of these recent and substantial changes in Icelandic family policies - in particular to assess whether Iceland has found a model which other countries, even the other Nordic countries, may want to aspire to. 


\section{References}

Ahn, N. and P.Mira. 2002. “A Note on the Changing Relationship Between Fertility and Female

Employment Rates in Developed Countries,” Journal of Population Economics. 15:4, pp. 667 - 82

Albrecht, J.W., P.-A. Edin,, M. Sundstrøm and S.B. Wroman. 1999. “Career Interruptions and subsequent earnings,” Journal of Human Resources. 34, pp. 294-311.

Albrecht, J., A. Bjorklund and S. Vroman. 2003. “Is There a Glass-Ceiling in Sweden?”. Journal of Labor Economics. 21:1, pp. 145-77.

Apps, P. and R. Rees. 2004. “Fertility, Taxation and Family Policy,” Scandinavian Journal of Economics. 106:4, pp. 745-63.

Asplund, R., E. Barth, N. Smith and E. Wadensjö. 1997. “The Male-Female Wage Gap in the Nordic Countries," in Wage Differentials in the Nordic Countries. Westergaard-Nielsen, ed., North Holland, Amsterdam.

Arulampalam, W., A.L. Booth and M.L.Bryan. 2004. "Is there a glass ceiling over Europe? Exploring the gender pay gap across the wages distribution.” IZA discussion paper no. 1373, IZA, Bonn.

Aslaksen, J., C. Koren and M. Stokstad. 2000. “The Effect of Child Care Subsidies. A Critique of the Rosen Model.” Feminist Economics. 6:1, pp. 95-103. 
Becker. G. 1964. Human Capital. N.Y. Columbia University Press.

Björklund, A. Forthcoming. “Does family policy affect fertility,” Journal of Population Economics.

Blanchflower, D.G. and A. Oswald. 1997. “The Rising Well-Being of the Young,” NBER Working Paper no 6102, NBER, Cambridge.

Blau, F.D and L.M. Kahn. 1992. ”The Gender Earnings Gap: Learning from International Comparisons.” American Economic Review. 82:2, pp. 533-38.

Blau, F.D. and L.M. Kahn. 1997. "Swimming Upstream: Trends in the Gender Wage Differential in the 1980s," Journal of Labor Economics. 15, 1-42.

Blau, F.D. and L.M. Kahn. 2003.’Understanding International Differences in the Gender Pay Gap.” Journal of Labor Economics. 21:1, pp. 106-44.

Blau, F.D. and L.M. Kahn. 2004. "The US gender pay gap in the 1990s: slowing convergence,” NBER working paper series, WP 10853, NBER, Cambridge

Bonke, J., N. Datta Gupta and N. Smith. 2005. “Timing and Flexibility of Housework and Men and Women's Wages," IZA Discussion paper \#860, IZA Bonn, in The economics of time use. D. Hamermesh and G.A. Pfann, eds. Elsevier, Amsterdam, pp. 43-77. 
Borchorst, A. 2003. “Gender, Power, and Decisions. Political negotiations on maternal leave 19012002 (in Danish),” Magtudredningen, Department of Political Science, University of Aarhus, Aarhus.

Cleveland, G. and M. Krashinsky. 2004. "Financing ECEC services in OECD countries,” Childcare Resource and Research Unit, University of Toronto. Downloadable from www.oecd.org/dataoecd/55/59/28123665.pdf

Cutler, D.M and J. Gruber. 1996. “Does Public Insurance Crowd Out Private Insurance?” The Quarterly Journal of Economics. 111:2, pp. 391-430.

Datta Gupta, N. and N. Smith. 2002. “Children and Career Interruptions: The Family Gap in Denmark.” IZA discussion paper \#263. Economica, 69:276, pp. 609-29.

Datta Gupta, N., R. Oaxaca and N. Smith. 2006. “Swimming Upstream, Floating Downstream: Comparing Women's Relative Wage Progress in the United States and Denmark,” Industrial and Labor Relations. 59:2, pp. 243-66

Del Boca, D., S. Pasqua and C. Pronzato. 2003. “Analyzing women’s employment and fertility rates in Europe: differences and similarities in Northern and Southern Europe,” Centre for Household, Income, Labour and Demographic Economics (CHILD), University of Torino, Torino. 
Edin, P.-A. and K. Richardson. 2002. "Swimming with the tide: Solidaric wage policy and gender earnings gap,” Scandinavian Journal of Economics. 104:1, pp. 49-67.

Einarsdóttir, B. and G. M. Pétursdóttir. 2004. “Culture, Custom, and Caring: Men’s and Women’s Possibilities to Parental Leave,” Centre for Gender Equality and Center for Womn’s and Gender Studies, University of Iceland, Akureyri

Ermisch, J. and M. Francesconi. 2001. “Family Structure and Mothers’ Behaviour and Children’s Achievements. Journal of Population Economics. 14.2, pp. 249-70.

Esping-Andersen, G. 2004. "Untying the Gordian Knot of Social Inheritance.” Research in Social Stratification and Mobility 21, pp. 115-39.

Freeman, R. and R. Schettkat. 2005. “Jobs and home work”. Economic Policy, January 2005, pp. 5-50.

Gregg, P., E. Washbrook, C. Propper and S. Burgess. 2005. “The effects of a mother’s return to work decision on child development in the UK.” The Economic Journal. 115, F48-F80.

Gustafsson, S. and F. Stafford. 1992. “Child Care Subsidies and Labor Supply. Sweden.Journal of Human Resources. 27:1, pp. 204-30. 
Gustafsson, S., C. Wetzels, J. D. Vlasblom, and S. Dex. 1996. “Women’s Labor Force Transitions in Connection with Childbirth: A Panel Data Comparison Between Germany, Sweden and Great Britain”, Journal of Population Economics, 9:3, pp. 223 - 246.

Gustafsson, S., E. Kenjoh, and C. Wetzel. 2002. First time mother's labor force transistions in Britain, Germany, the Netherlands and Sweden, in H. Mosley, J. O’Reilly and K. Schönmann (eds.) Labor Markets, Gender and Institutional Change, Essays in Honour of Günther Schmid, Edgar Elgar, Cheltenham, UK.

Hardoy, I. and P. Schøne. 2004. "Levels and changes in the family gap: Evidence from a family friendly environment, unpublished paper, Institute for Social Research, Oslo.

Haataja, A. and A. Nyberg. 2005. "Redesign of the dual earner-dual career model in Nordic countries,” paper presented at a seminar at Danish National Social Research Institute, April 2005, Copenhagen.

Hank, K. and M. Kreyenfeld. 2000. "Does the availability of childcare influence the employment of mothers? Findings from Western Germany”, Population Research and Policy Review. 19:4, pp. 317-337.

Henrekson, M. 2004. Vägar till ökad jämställdhet i svenskt näringsliv. SNS forlag, Stockholm 
Hiilamo, H. and O. Kangas. 2005. "Trap for women or freedom to choose? Political frames in the making of child home care allowance in Finland and Sweden,” Working paper.

Jaumotte, F. 2004. "Labour force participation of women: empirical evidence on the role of policy and others determinants in OECD countries,” OECD Economic Studies. 37, 2003/2, Paris.

Kangas, O. and T. Rostgaard. 2005.” Preferences or care context. Opinions on family and employment in seven European countries.” Working paper.

Laine, V. 2002. “Evaluating tax and benefit reforms in 1996-2001,” VATT-Discussion papers, Government Institute for Economic Research, Helsinki

Nielsen, H.S, M. Simonsen and M. Verner. 2004. "Earnings Effects of Children in a Model with Endogenous Sector Choice”. The Scandinavian Journal of Economics. 106:4, pp. 721-44.

NOSOSCO. 2002. "Social Protection in the Nordic Countries 2002.” Chapter 4 in Families and Children, http://www.nom-nos.dk/nososco.htm.

Pylkkänen, E. 2002. “Studies on household labor supply and home production, Economic Studies,” Department of Economics, School of Economics and Commercial Law, Gothenburg University, No. 120, Gothenburg. 
Pylkkänen, E. and N. Smith. 2004. “The Impact of Family-Friendly Policies in Denmark and Sweden on Mothers' Career Interruptions Due to Childbirth,” IZA Discussion Paper no. 1050, IZA Bonn.

OECD. 2001, 2002a. Employment Outlook, Paris.

OECD. 2002b, 2003, 2004, 2005. Babies and Bosses, Reconciling work and family life, Paris

Rosen, S. 1996. "Public Employment and the Welfare State in Sweden,” Journal of Economic Literature. 34:2, pp. 729-40.

Rosholm M. and N. Smith. 1996. “The Danish Gender Wage Gap in the 1980s: A Panel Data Study,” Oxford Economic Papers. 48, pp. 254-79

Ruhm, C. 1998. “The Economic Consequences of Parental Leave Mandates: Lessons from Europe,” Quarterly Journal of Economics. 113, pp. 285-317.

Ruhm, C. 2004. "Parental Employment and Child Cognitive Development.” Journal of Human Resources. 39:1, pp. 155-92

Rønsen, M. and M. Sundström. 1996. ”Maternal Employment in Scandinavia: A Comparison of the After-birth Employment Activity of Norwegian and Swedish Women.” Journal of Population Economics. 9, pp. 267-85. 
Rønsen, M and M Sundström. 2002. "Family policy and after-birth employment among new mothers.” European Journal of Population. 18, pp. 121-52.

Rønsen, M. 2004. "Fertility and Public Policies - Evidence from Norway and Finland.” Demographic Research. 10:6, Max-Planck-Gesellschaft, Rostock, www.demographic-research.org

Schøne, P. 2005. “The Effect of a Family Policy Reform on Mother’s Pay: A Natural Experiment Approach," Review of Economics of the Household. 3:2, pp. 145-170.

Simonsen, M. 2005. “Availability and Price of High Quality Child Care and Female Employment,” working paper, University of Aarhus.

Smith, N., T. Callan, S. Dex and J.D. Vlasblom. 2003. “Taxation of Spouses: A Cross Country Study of the Effects on Married Women’s Labour Supply”, Oxford Economic Papers. 55:3, pp 417-39.

Smith, N., V. Smith, and M. Verner. 2005. "Do Women in Top Management Affect Firm Performance? A Panel Study of 2500 Danish Firms,” IZA DP 1708, IZA, Bonn

SOU. 2003. “En jämställd föräldraförsäkring?” Bilaga 12 till LU 2003, SOU 2003:36, Stockholm

Sundström, M. and A. Dufvander. 2002. “Gender division of childcare and the sharing of parental leave among new parents in Sweden.” European Sociological Review. 18, pp. 433-47. 
Waldfogel, J. 1998. “Understanding the ‘Family Gap’ in Pay for Women with Children.” Journal of Economic Perspectives. 12:1, pp. 137-56.

Waldfogel, J., Y. Higuchi and M. Abe. 1999. “Family Leave Policies and Women’s Retention After Childbirth: Evidence from the United States, Britain, and Japan.” Journal of Population Economics. 12:4, pp. 523-46.

Waldfogel, J. 2002. “Child care, women’s employment and child outcomes.” Journal of Population Economics. 15, pp. 527-48.

Waldfogel, J. 2004. “Social Mobiliy, Life Chances and the Early Years,” CASE paper 88, Center for Analysis of Social Exclusion, London School of Economics, London

Walker, J.R. 1995. “The effects of public policies on recent Swedish fertility behavior,” Journal of Population Economics. 8, pp. 223-51 
Figure 1. Paid Maternal leave, weeks. 1999.

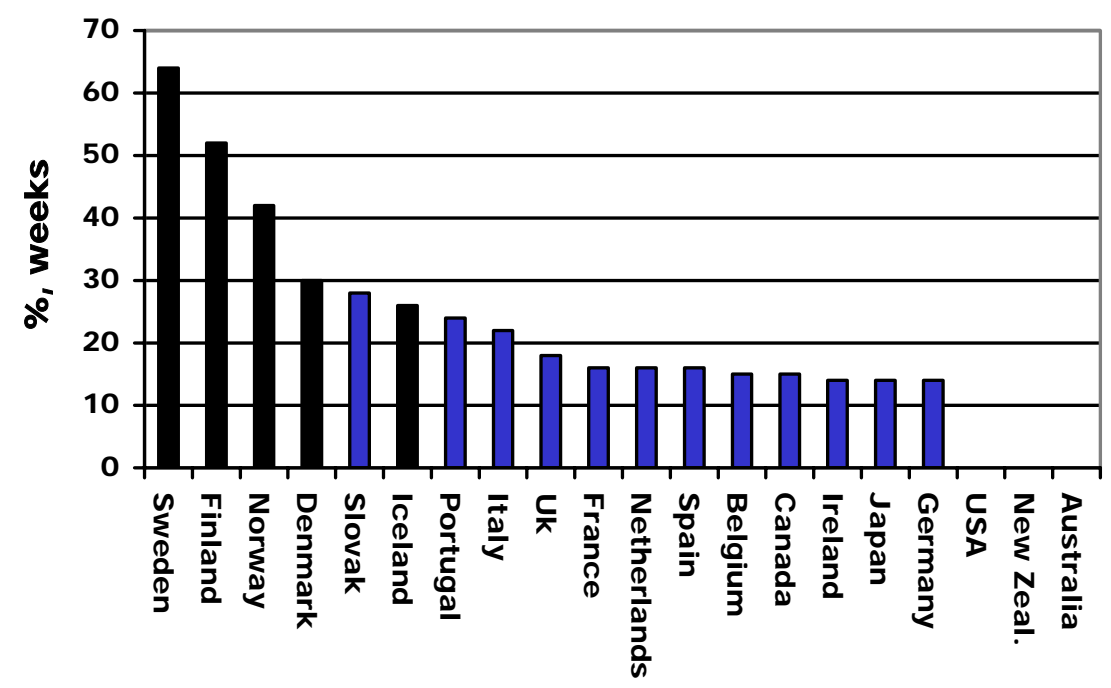

Source: OECD (2001, Table 4.7). 
Figure 2. Child care coverage (\%) for children 0-2. Public or private formal child care.

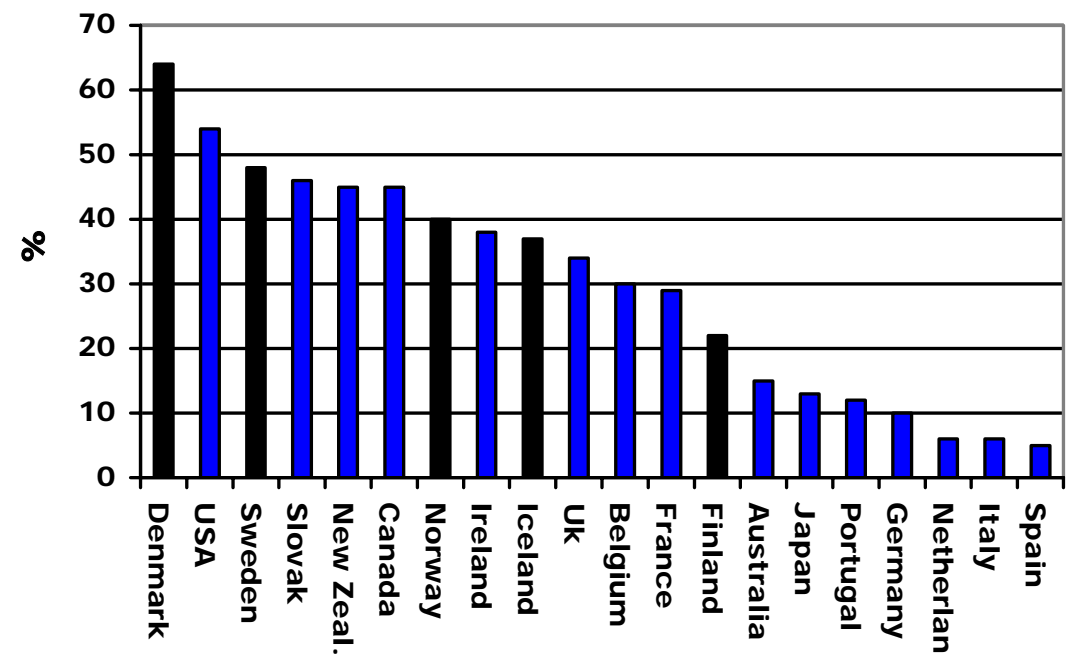

Note: The figures refer to the years 1998-2000 for most of the countries, except for the U.S. (1995) and Norway (1997), Iceland (1995).

Source: OECD (2001, Table 4.7) and for Iceland NOSOSCO (2002). 
Figure 3. Employment Rates for Women in Families with a Child less than 6. 1999.

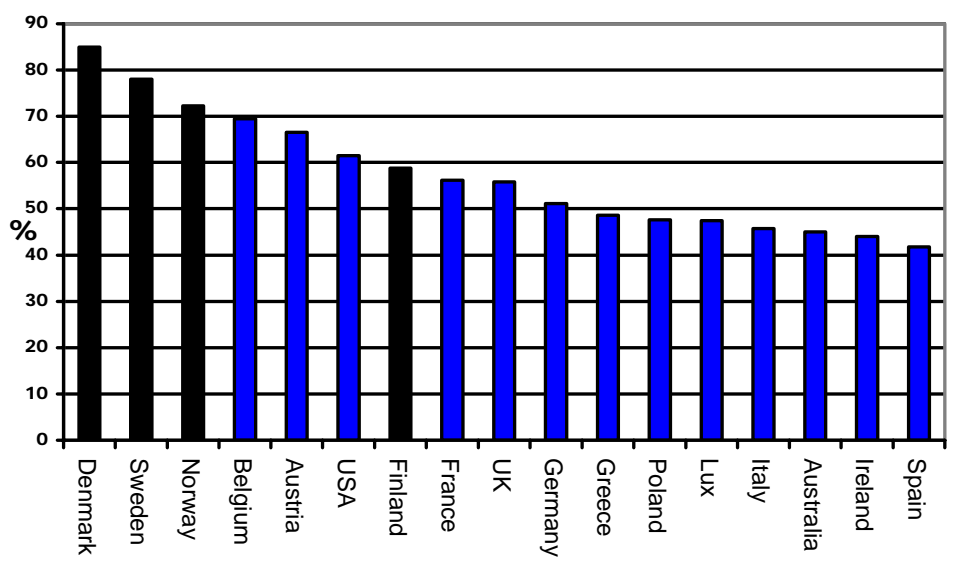

Source: OECD (2001, Table 4.1). 
Figure 4. Employment rates for women aged 20-34 in the Nordic countries.
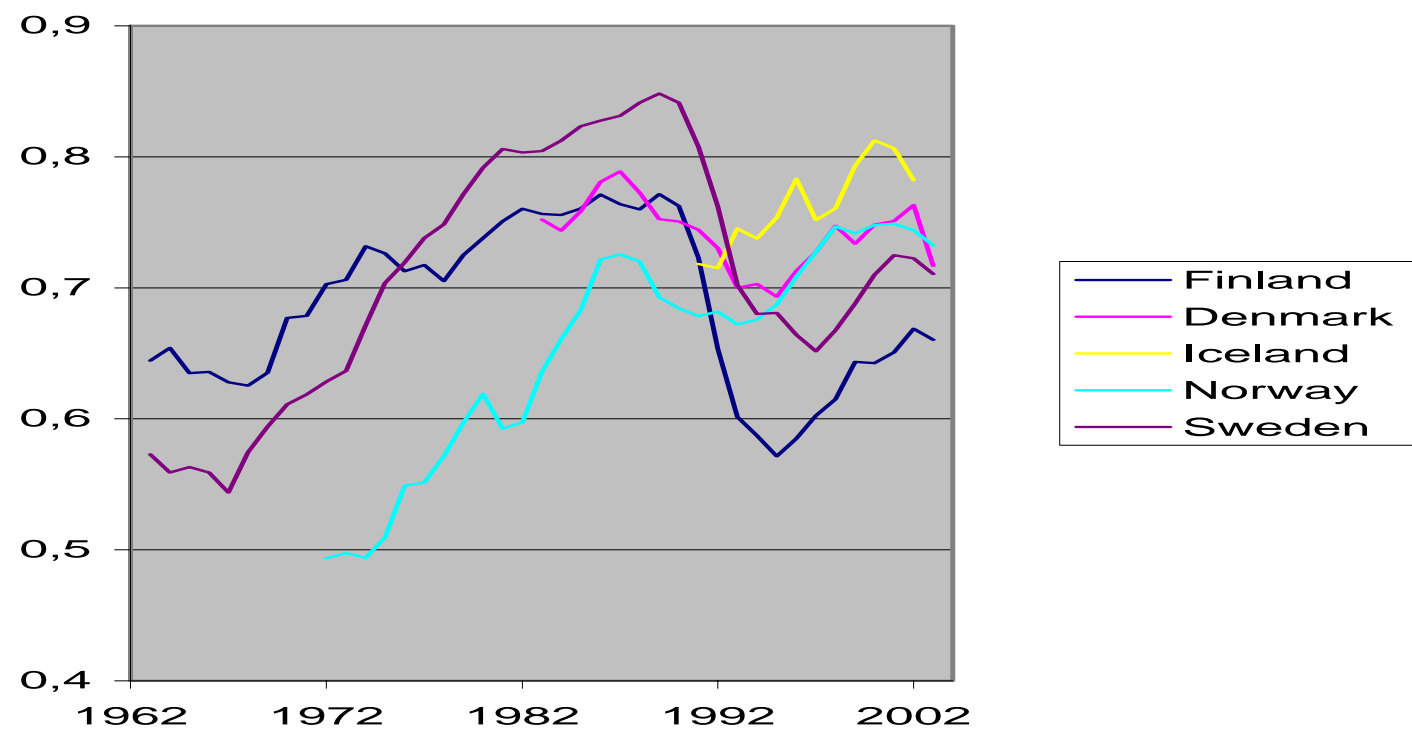

Source: OECD labor market statistics. 
Figure 5. Gender Wage Gap in selected OECD countries 2002, Industry and Services. Gross earnings for full-time workers in industry and services.

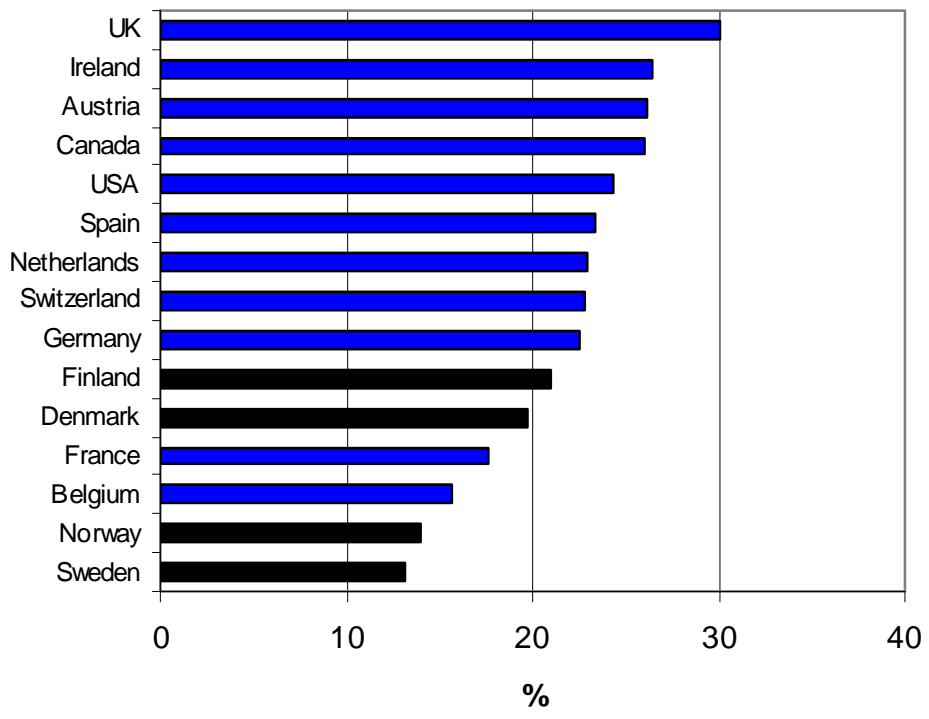

Source: EUROSTAT, Statistics Norway, and US Census Bureau 
Figure 6. The development of the female-to-male wage ratio in the Nordic countries. Manual workers in the private sector.

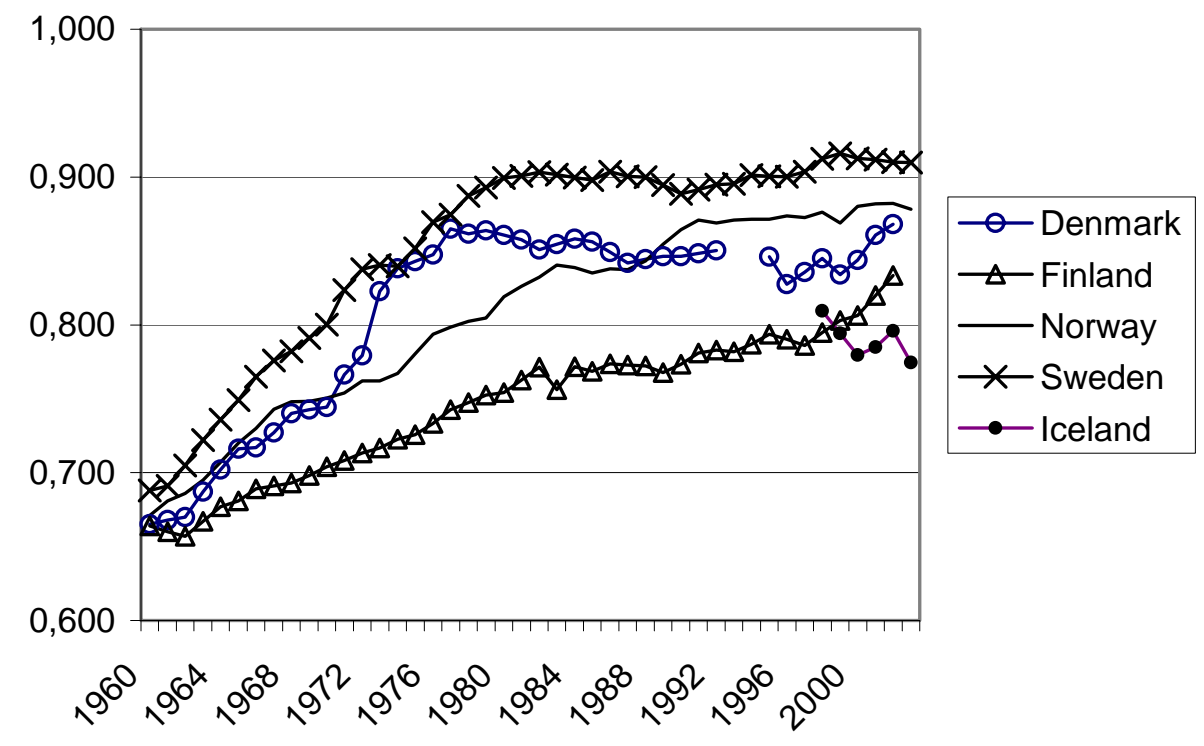

Source: ILO database for yearbook of labor statistics, LABORSTA, and national Statistical Bureaus. 
Table 1. Child care coverage: Children enrolled in child care and municipal family day care as a percentage of the respective age groups

\begin{tabular}{|c|c|c|c|c|c|}
\hline & Denmark & Finland & Iceland $^{1)}$ & Norway & Sweden \\
\hline \multicolumn{6}{|l|}{1990} \\
\hline $0-6$ years & 61 & 44 & --- & 33 & 48 \\
\hline \multicolumn{6}{|l|}{1995} \\
\hline $0-2$ years & 48 & 18 & 37 & 22 & 37 \\
\hline 3-6 years & 83 & 55 & 64 & 61 & 74 \\
\hline $7-10$ years & 53 & 5 & --- & --- & 45 \\
\hline \multicolumn{6}{|l|}{2002} \\
\hline $0-1$ years & 9 & 1 & 8 & 2 & 0 \\
\hline $1-2$ years & 78 & 36 & 72 & 40 & 65 \\
\hline 3-5 years & 94 & 67 & 93 & 82 & 91 \\
\hline 6 years & 90 & 68 & --- & --- & 83 \\
\hline $7-10$ years & 66 & 3 & --- & --- & 58 \\
\hline
\end{tabular}

Note 1: From 1995 on, only children aged 0-5 years are included.

Source: NOSOSCO (2002) 
Table 2. The share of the total leave period (incl. maternal, paternal, parental leave and daddy days) taken up by the father

\begin{tabular}{|l|c|c|c|c|c|}
\hline & Denmark & Finland & Iceland & Norway & Sweden \\
\hline 1990 & 4,2 & --- & --- & --- & 7,7 \\
\hline 1995 & 4.4 & 3.6 & 0.1 & 5.8 & 10.3 \\
\hline 1996 & 6,5 & --- & --- & --- & 10,6 \\
\hline 1997 & 5,7 & --- & --- & --- & 9,9 \\
\hline 1998 & 5,4 & --- & --- & --- & 10,4 \\
\hline 1999 & 5,6 & --- & --- & --- & 11,6 \\
\hline 2000 & 5,5 & 4.1 & 3.3 & 7.2 & 13.7 \\
\hline 2001 & 5.7 & 4.3 & 11.5 & 8.3 & 15.0 \\
\hline 2002 & 5.5 & 4.8 & 19.6 & 8.6 & 16.6 \\
\hline 2003 & 5,9 & --- & 31.3 & 13,2 & --- \\
\hline 2004 & 4,7 & 5,4 & --- & 13,7 & --- \\
\hline
\end{tabular}

Note: For the years 1995, 2000-02 the figures includes leave periods related to birth and adoption while adoption is not included for the other years.

Source: NOSOSCO (2003) (1995,2000-02). For other years: Statistics Denmark, Unpublished statistics, Kela

(Finland), Statistics Norway, SOU (2003) (Sweden), Sundström and Dufvander (2002) (Sweden), Einarsdóttir and Pétursdóttir (2004) (Iceland). 
Table 3. Decomposition of changes in the Danish gender wage gap. Full-time employed salaried workers. 1983-1995.

\begin{tabular}{|l|c|c|c|c|c|c|}
\hline & \multicolumn{3}{|c|}{ Denmark } & \multicolumn{3}{c|}{ US } \\
\hline & $\begin{array}{c}1 \text { st } \\
\text { decile }\end{array}$ & Mean & $\begin{array}{c}9 \text { th } \\
\text { decile }\end{array}$ & $\begin{array}{c}1 \text { st } \\
\text { decile }\end{array}$ & Mean & $\begin{array}{c}9 \text { th } \\
\text { decile }\end{array}$ \\
\hline Change in gender wage gap & $-2.4 \%$ & $5.4 \%$ & $14.8 \%$ & $0.3 \%$ & $-9.6 \%$ & $-10.3 \%$ \\
Due to: & $1.9 \%$ & $1.0 \%$ & $-2.2 \%$ & $-7.1 \%$ & $-10.9 \%$ & $-14.2 \%$ \\
Observed qualifications & $-4.3 \%$ & $4.4 \%$ & $17.0 \%$ & $7.2 \%$ & $1.3 \%$ & $1.3 \%$ \\
Unobserved factors etc. & & & & & & \\
\hline
\end{tabular}

Source: Datta Gupta et al. (2006) 
Table 4. Total fertility rate and female employment rates, early 1970s and 2000s.

\begin{tabular}{|l|c|c|c|c|}
\hline & \multicolumn{2}{|c|}{$1970-1975$} & \multicolumn{2}{c|}{$2000-2005$} \\
\hline & $\begin{array}{c}\text { Total Fertility } \\
\text { Rate }\end{array}$ & $\begin{array}{c}\text { Female } \\
\text { Employment } \\
\text { Rate age 25-54 }\end{array}$ & $\begin{array}{c}\text { Total Fertility } \\
\text { Rate }\end{array}$ & $\begin{array}{c}\text { Female } \\
\text { Employment } \\
\text { Rate age 25-54 }\end{array}$ \\
\hline Denmark & 1.95 & 76.8 & 1.76 & 78.9 \\
\hline Finland & 1.82 & 70.4 & 1.76 & 78.8 \\
\hline Iceland & 2.81 & 80.8 & 1.99 & 85.7 \\
\hline Norway & 2.50 & 51.7 & 1.80 & 79.7 \\
\hline Sweden & 1.92 & 63.4 & 1.71 & 81.7 \\
\hline & & & & 7.7 \\
\hline Belgium & 2.25 & 45.8 & 1.61 & 67.7 \\
\hline Germany & 2.03 & 47.0 & 1.34 & 72.0 \\
\hline Spain & 2.90 & 24.8 & 1.29 & 56.5 \\
\hline France & 2.47 & 49.2 & 1.89 & 71.8 \\
\hline UK & 2.43 & 60.3 & 1.71 & 74.1 \\
\hline Greece & 2.39 & 40.1 & 1.27 & 56.6 \\
\hline Ireland & 3.93 & 22.1 & 1.98 & 65.1 \\
\hline Italy & 2.42 & 27.9 & 1.29 & 54.9 \\
\hline Netherlands & 2.57 & 22.6 & 1.75 & 73.9 \\
\hline Poland & 2.20 & 67.7 & 1.24 & 62.1 \\
\hline Portugal & 2.83 & 45.9 & 1.44 & 74.2 \\
\hline United States & $\left.2.00 *^{*}\right)$ & 47.8 & 2.07 & 72.0 \\
\hline Japan & 2.10 & 54.7 & 1.38 & 64.4 \\
\hline Korea & $\left.4.30 *^{*}\right)$ & 47.0 & $\left.1.49 *^{*}\right)$ & 56.8 \\
\hline & & & & \\
\hline Correlation & & & & 0.668 \\
\hline Soure & & & & \\
\hline
\end{tabular}

Source: Employment data: OECD Labour Market Statistics. Fertility data: Eurostat. Numbers marked by $(*)$ are from Human development report. Period 1970-75 and 2000-2005. Exceptions are for female employment rate 1970-1975: Denmark, Belgium and Greece (1983), Iceland (1991), UK (1984), Poland (1992). 
Table 5. Percentage of GDP spent on publicly provided child care and leave schemes in selected OECD countries.

\begin{tabular}{|c|c|c|c|}
\hline & $\begin{array}{c}\text { \% of GDP spent on } \\
\text { publicly financed } \\
\text { leave schemes }\end{array}$ & $\begin{array}{l}\text { \% of GDP on publicly } \\
\text { provided child care and } \\
\text { pre-school services }\end{array}$ & $\begin{array}{c}\% \text { of GDP on publicly } \\
\text { provided child care and } \\
\text { leave schemes }{ }^{1)}\end{array}$ \\
\hline Denmark & 0.5 & 2.7 & 3.2 \\
\hline Finland & 0.6 & 1.5 & 2.1 \\
\hline Iceland & 0.6 & 1.1 & 1.7 \\
\hline Norway & 0.5 & 1.6 & 2.1 \\
\hline Sweden & 0.8 & 1.9 & 2.7 \\
\hline Australia, & 0.0 & 0.3 & 0.3 \\
\hline Austria, & 0.6 & 0.9 & 1.5 \\
\hline Canada & 0.2 & 0.3 & 0.5 \\
\hline France & ? & 1.3 & ? \\
\hline Germany & 0.1 & 0.8 & 0.9 \\
\hline Ireland & 0.1 & 0.5 & 0.6 \\
\hline Japan & 0.1 & 0.3 & 0.4 \\
\hline Netherlands & 0.2 & 0.2 & 0.4 \\
\hline New Zealand & 0.0 & 0.3 & 0.3 \\
\hline Portugal & 0.1 & 0.5 & 0.6 \\
\hline Switzerland & 0.1 & 0.3 & 0.4 \\
\hline UK & 0.1 & 0.5 & 0.6 \\
\hline US & 0.0 & 0.5 & 0.5 \\
\hline \multicolumn{4}{|c|}{ Simple cross country correlation between \% of GDP and fertility/female employment: } \\
\hline Fertility & 0.412 & 0.343 & 0.424 \\
\hline Female employment & 0.664 & 0.564 & 0.630 \\
\hline
\end{tabular}

Note 1 . The figure includes only public expenditures on leave schemes, not expenditures paid by the employer. For the public sector, only the costs related to the leave scheme are included, not the employer specific costs due to collective agreements on for instance full payment during leave.

Source: OECD (2002b, 2003, 2004a, 2005), Jaumotte (2004) and Eurostat (information on leave schemes for Germany, Iceland, Norway). Information on leave schemes refers to the years 2001-03 and child care 1999. 


\section{Endnotes:}

${ }^{1}$ See Jaumotte (2004). However, for Iceland there are still considerable disincentives for second earner labor supply.

2 The United States introduced an unpaid leave period (cf. the FMLA) in 1993.

${ }^{3}$ The concept of 'parental leave' also includes the Danish 'child care leave' scheme. We do not include in the definition of 'leave' the Finnish and Norwegian cash subsidy for child care because these schemes are very different from traditional leave schemes.

${ }^{4}$ Although certain large groups in the labor market have negotiated special agreements with even higher replacement rates, e.g. 90\% of former earnings in the case of all state and government employees in the public sector in Sweden.

${ }^{5}$ When the compensation is based on former earnings and the maternal leave periods are long as in the Nordic countries, an important question is whether the compensation is based on former hourly or annual earnings. In Sweden, it is former annual income, and this means that the compensation rate declines over time if the mother gives birth to additional children within a few years i.e. she has no or little employment between childbirths. It can be said that Sweden has a 'speed premium' which implies that women who give birth to their second or subsequent child within a relatively short time period after the birth of a child can maintain the benefit level, despite their previous wage income not qualifying for this benefit level. In Denmark, the compensation is based on previous hourly or monthly earnings, not annual income, and thus, the compensation rate does not usually decline over time.

${ }^{6}$ Hiilamo and Kangas (2005) attribute this in part to the prevailing political discourse in Finland which has emphasized the positive qualities of home care and women's “freedom to choose”, 
contrasted to the very different debate in Sweden and other Nordic countries where home-based care has been seen as a “trap for women”.

${ }^{7}$ The definition of participation rates may overstate the 'real' attachment to the labor market if mothers on maternal leave from a job are registered as being labor force participants. This is typically the case for mothers on formal leave in the Nordic countries. For this purpose, employment rates may be more reliable.

${ }^{8}$ This permanent loss may reflect different career paths and promotion chances for men and women in the private sector. For instance, the number of women who reach top positions (CEOlevel) in the Nordic countries is low compared to many other countries; see Smith et al. (2005) and Henrekson (2004).

${ }^{9}$ These jobs are not typically low paid jobs in the sense that they often demand high qualifications and education, and also offer full job protection and full rights to social security goods etc.

${ }^{10}$ In fact, a relevant question which we do not address here could be to what extent publiclyprovided care and services tends to “crowd out” private care. See for example Cutler and Gruber (1996) for an analysis of this type on the insurance market 